\title{
GENERAL ANAESTHESIA FOR RENAL TRANSPLANTATION IN LATVIA: A CRITICAL ANALYSIS BASED ON CLINICAL EXPERIENCE
}

\author{
Antoṇina Sondore, Sanita Ūdre, Jānis Nemme, Laimdota Grašiṇa, leva Kruževṇaka, \\ Inta Matulēna, Vija Rozīte, Lìga Mitre, Ivonna Vìtola, Danuta Viskante, \\ Juris Aprups, Anita Berga, Juris Bormotovs, and Indulis Kokars
}

Department of Anaesthesiology and Reanimatology, Pauls Stradinš Clinical University Hospital,

Pilsoṇu iela 13, Rīga, LV-1002, LATVIA; antonina.sondore@gmail.com

Communicated by Rafails Rozentāls

\begin{abstract}
Anaesthesia methods for surgical procedures, as well as for organ transplantation, have experienced remarkable changes over the past 40 years. Cadaveric renal transplant function may be impaired by haemodynamic instability induced by anaesthesia drugs. This study aimed to analyse the safety and effectiveness of the different anaesthesia methods used for renal transplantation in Latvia since 1973, with focus on its haemodynamic effects. In this retrospective study anaesthesia chart review was conducted for 607 patients (pts), aged 17-75 yrs, ASA III/IV, undergoing renal transplantation using general anaesthesia in the following periods: 1973-1990 (stage I - 282 pts); 1991-2000 (stage II - 145 pts); 2001-2011 (stage III - 180 pts). Haemodynamic data (systolic, diastolic, mean arterial blood pressure and central venous pressure) were measured prior to premedication and induction of anaesthesia, immediately afterwards, during the surgery and up to its completion with the special attention regarding the time of graft reperfusion. The main perioperative problems of the anaesthesia methods used during stage I (barbiturates, viadril, neuroleptanalgesics, sodium oxybutyrate, halothane, nitrous oxide) was haemodynamic instability in $60 \%$ of cases and apnea due to central depression and long-time peripheral neuromuscular blockade. Two patients died due to underlying comorbid conditions, including hyperhidration and oedema pulmonum. Substantial haemodynamic changes during total intravenous anaesthesia with propofol and combined anaesthesia propofol-isoflurane (stage II) were not observed. At the time of graft reperfusion, the incidence of hypotension was slightly higher in patients anaesthetised with isoflurane than in those who received sevoflurane (stage III), but this difference was not significant ( $\mathrm{P}>0.05)$. Kidney functioned immediately in $75 \%$ of cases and delayed function was observed in $25 \%$ of cases in sevoflurane and isoflurane groups. The modern anaesthetic agents provide a great margin of safety during renal transplantation. Total intravenous anaesthesia with midasolam-fentanyl-propofol and general anaesthesia with propofol-isoflurane, propofol-sevoflurane can be safely used. During renal transplantation, anaesthesiologists must optimise volume status, perfusion pressure and promote survival of the renal graft.
\end{abstract}

Key words: anaesthesia, renal transplantation.

\section{INTRODUCTION}

The programme of kidney transplantation in Latvia was started in 1973. The growing number of kidney transplantations during the subsequent period raised new aspects in anaesthetic management. It was found that the incidence of post-operative acute tubular necrosis or delayed graft function after cadaveric transplantation depends on many factors and one of them is haemodynamic stability during reperfusion of transplant. For renal transplantation, the major anaesthetic consideration is maintenance of renal blood flow. Typical haemodynamic goals during reperfusion are systolic blood pressure (SBP) above $120-130 \mathrm{~mm} \mathrm{Hg}$ and tar- get central venous pressure $(\mathrm{CVP}) \geq 10-12 \mathrm{~mm} \mathrm{Hg}$. Below these values, there is an increased incidence of acute tubular necrosis (Akpek et al., 2002; Thomas et al., 2003; Pericol et al., 2004). Taking into account that during anaesthesia there is interaction between intravenous induction agents, inhalational anaesthetics and haemodynamics, this study aimed to provide an overview and critical analysis of past anaesthetic management for renal transplantation, based on 40 years of clinical experience. The main aim of this study was to evaluate the haemodynamic effects of different anaesthesia methods, with focus on time of graft revascularisation and kidney survival. 


\section{MATERIALS AND METHODS}

After approval by the hospital Ethics Committee a retrospective anaesthesia chart review was conducted for patients undergoing renal transplantation using general anaesthesia during the period 1973 to 2011 yrs. In total, 607 patients, aged 17-75 yrs, ASA (American Society of Anesthesiologists physical state scale) III/IV, sheduled for cadaver-related kidney transplantation were included in this study. The most common causes of renal disease leading to kidney transplantation were chronic glomerulonephritis, polycystic kidney disease, diabetes, nephrosclerosis, and interstitial nephritis. Exclusion criteria for study were patients with severe cardiovascular co-morbidity. Patients (pts) were divided into three groups based on year of transplantation: 1973-1990 (stage I - 282 pts); 1991-2000 (stage II -145 pts); 2001-2011 (stage III - 180 pts). This division was used since the periods differed in the types of anaesthetics used for kidney transplantation.

a) During stage $\mathbf{I}$ the drugs available in Latvia for general anaesthesia were used. The choice of drugs was dependent on haemodynamic data and excretory kidney function of the recipients prior to operation (mainly ability to excrete water). For comparative assessment of the suitability and safety of the used anaesthesia methods, a patient sample group 282 from 400 operated patients was chosen arbitrarily, taking into account comparable demographic data, co-morbidity and cold ischemia time of the donor organ. Characteristics of the anaesthesiological management used for renal transplantation during stage I is given in Table 1 .

b) Stage II was characterised by introduction in clinical practice in 1990 of short-acting benzodiazepine midasolam and the neuromuscular blocking drug (NMBD) atracurium (Sondore and Rozite, 1990; Fahey et al., 1984), the elimination of which is completely independent of kidney function (Sondore et al., 1994). Since 1994, short-acting intravenous anaesthetics propofol, which is intensively metabolised in the organism (Kirvela et al., 1992), was implemented in the anaesthesia system. Propofol is an intravenous agent suitable for both induction and maintenance of anaesthesia. Studies of propofol in uraemic patients indicated no alteration in terminal half-life or clearance. Less than $0.3 \%$ of propofol is excreted unchanged in the urine. Use of propofol for total intravenous abnaesthesia during renal transplantation has also been reported (de Gasperi et al., 1996; Mitre et al., 1994). Total intravenous anaesthesia (TIVA) using propofol in combination with strong shortacting opioid fentanyl, benzodiazepine midasolam and NMBD atracurium became the one of the methods of choice for induction and maintenance of anaestesia for renal transplantation, and was utilised in 80 patients (Mazze et al., 1974).

A new volatile non-toxic anaesthetic, isoflurane, for maintenance of anaesthesia was available from 1994 (Sondore $e t$ al., 1994; 1998; 2000). Isoflurane undergoes little biotransformation (only $0.2 \%$ ), lacks nephrotoxic metabolites, and has less cardiac depression than halothane. In this study, 65 patients anaesthetised with isoflurane were selected for analysis in accordance with demographics, co-morbidity and equal cold ischemia time of graft.

The haemodynamic effects of a total intravenous anaesthesia with combination of propofol with fentanyl and midasolam (TIVA patient group, $\mathrm{n}=80$ ) was comparatively evaluated with the effects of anaeshesia provided by the combination of the volatile anaesthetic isoflurane with fentanyl and midasolam isoflurane patient group "a", $\mathrm{n}=65$ ). In both groups propofol was used for induction of anaesthesia. Characteristics of anaesthetic management for renal transplantation in 145 patients in 1991-2000 are given in Table 2.

c) Stage III. Sevoflurane as a component of balanced general anaesthesia was introduced in clinical practice in 2000, but was used for renal transplantation only since 2008, as it was considered as an anaesthetic with potential nephrotoxicity (Eger et al., 1997). Its metabolic products (inorganic fluoride and compound „A”) can produce renal injury. However some clinical studies reported no evidence of nephrotoxicity (Kharasch et al., 1997). In this study the haemodynamic changes during anaesthesia (sevoflurane group, $\mathrm{n}=90$ pts.) using sevoflurane was evaluated comparatively with those of isoflurane (isoflurane patient group "b", $\mathrm{n}=90$ ), which continued to be used in renal transplantation in 2008-2011 (Table 3).

Table 1

METHODS OF GENERAL ANAESTHESIA FOR RENAL TRANSPLANTATION IN 282 PATIENTS IN 1973-2000

\begin{tabular}{|c|c|}
\hline Direct premedication & Agents for induction, $n$, number of patients \\
\hline $\begin{array}{l}\text { Diazepam 5-10 mg; } \\
\text { Atropin } 0.5-0.8 \mathrm{mg}\end{array}$ & Viadril $1-0 \mathrm{~g}(\mathrm{n}=24)$ \\
\hline $\begin{array}{l}\text { Promedol } 20 \mathrm{mg} \text {; } \\
\text { Dimedrol } 20 \mathrm{mg} \text { (standardised for all patients) i/v }\end{array}$ & $\begin{array}{l}\text { Thiopental, } 3-4 \mathrm{mg} / \mathrm{kg} \text { with fentanyl and droperidol }(\mathrm{n}=142) \text {; } \\
\text { Sodium oxybutyrate, } 2.0-4.0 \mathrm{~g} \text {, combined with thiopental } 0.1-0.2 \mathrm{~g}(\mathrm{n}=96) \text {; } \\
\text { Neuroleptanalgesia (NLA): droperidol } 12.5-17.6 \mathrm{mg} \text {, fentanyl } 0.25-0.4 \mathrm{mg}+\mathrm{N} 2 \mathrm{O}(\mathrm{n}=20)\end{array}$ \\
\hline Agents for maintanance & $\begin{array}{l}\text { Nitrous oxide }(\mathrm{N} 2 \mathrm{O}) \text {, combined with } \mathrm{i} / \mathrm{v} \text { NLA, }(\mathrm{n}=252) \text {; } \\
\text { Halothane or its combination with ether combined with fentanyl }(\mathrm{n}=30)\end{array}$ \\
\hline Neuromuscular blocking drugs (NMBD) & $\begin{array}{l}\text { Succinylcholine, } \\
\text { Dioxonium, } \\
\text { d-tubocurarine }\end{array}$ \\
\hline
\end{tabular}


CHARACTERISTICS OF ANAESTHETIC MANAGEMENT FOR RENAL TRANSPLANTATION IN 145 PATIENTS IN 1991-2000

\begin{tabular}{|c|c|c|}
\hline Patient group, $\mathrm{n}$ & Induction of anaesthesia & Maintenance of anaesthesia \\
\hline $\begin{array}{l}\text { Pripofol group } \\
n=80\end{array}$ & $\begin{array}{l}\text { Propofol } 1.6-2.2 \mathrm{mg} / \mathrm{kg} \\
\text { Fentanyl } 1.5-2.0 \mathrm{mkg} / \mathrm{kg} \\
\text { Atracurium } 0.5 \mathrm{mg} / \mathrm{kg}\end{array}$ & $\begin{array}{l}\text { Propofol } 6-8 \mathrm{mg} / \mathrm{kg} \text { for first } \\
15 \mathrm{~min} \text {, } \\
\text { followed by } 4-6 \mathrm{mg} / \mathrm{kg} \text { for } \\
\text { next } 15 \mathrm{~min}, \\
\text { followed by } 2-4 \mathrm{mg} / \mathrm{kg} \text { until } \\
\text { skin closure } \\
+ \text { supplementary doses of } \\
\text { fentanyl }(0.1 \mathrm{mg}) \\
\text { and atracurium }\end{array}$ \\
\hline $\begin{array}{l}\text { Isoflurane group } \\
\mathrm{n}=65\end{array}$ & $\begin{array}{l}\text { Propofol } 1.6-2.2 \mathrm{mg} / \mathrm{kg} \\
\text { Fentanyl } 1.5-2.0 \mathrm{mkg} / \mathrm{kg} \\
\text { Atracurium } 0.5 \mathrm{mg} / \mathrm{kg}\end{array}$ & $\begin{array}{l}\text { Isoflurane }(0.8-1 \mathrm{MAK}) \\
+ \text { supplementary doses of } \\
\text { fentanyl }(0.1 \mathrm{mg})\end{array}$ \\
\hline
\end{tabular}

Table 3

CHARACTERISTICS OF ANAESTHETIC MANAGEMENT FOR RENAL TRANSPLANTATION IN 180 PATIENTS DURING 2008-2011

\begin{tabular}{|c|c|c|}
\hline$\underline{\text { Patient group, } \mathrm{n}}$ & Induction of anaesthesia & Maintenance of anaesthesia \\
\hline $\begin{array}{l}\text { Sevoflurane group, } \\
n=90\end{array}$ & $\begin{array}{l}\text { Propofol } 1.6-2.2 \mathrm{mg} / \mathrm{kg} \\
\text { Fentanyl } 1.5-2.0 \mathrm{mkg} / \mathrm{kg} \\
\text { NMBD Atracurium } 0,5 \\
\mathrm{mg} / \mathrm{kg}\end{array}$ & $\begin{array}{l}\text { Sevoflurane }(0.8-1 \text { MAK }) \\
\text { + supplementary doses of } \\
\text { fentanyl }(0.1 \mathrm{mg})\end{array}$ \\
\hline $\begin{array}{l}\text { Isoflurane group, } \\
\mathrm{n}=90\end{array}$ & $\begin{array}{l}\text { Propofol } 1.6-2.2 \mathrm{mg} / \mathrm{kg} \\
\text { Fentanyl } 1.5-2.0 \mathrm{mkg} / \mathrm{kg} \\
\text { Atracurium } 0.5 \mathrm{mg} / \mathrm{kg}\end{array}$ & $\begin{array}{l}\text { Isoflurane }(0.8-1 \mathrm{MAK})+ \\
\text { supplementary doses of } \\
\text { fentanyl }(0.1 \mathrm{mg})\end{array}$ \\
\hline
\end{tabular}

In all patients of the three stages of study, preoperative haemodialysis was provided $24-48 \mathrm{~h}$ before renal transplantation. Before surgery and anaesthesia, patients underwent full medical and surgical history and routine laboratory investigation (i.e. blood $\mathrm{Hb}, \mathrm{Ht}$, plasma proteins, coagulation studies, biochemical tests and serum electrolytes, blood glucose, chest radiograph and electrocardiography) and were evaluated by anaesthesiologists. In 15 patients with ESRD and severe anaemia, blood samples for electronic microscopic evaluation of erythrocytes morphology were obtained. During stage I, monitored vital functions of patients were arterial blood pressure and pulse, peripheral temperature, ECG, pulse oximetry, as well as clinical signs of anaesthesia. Since the start of stage II of anaesthetic management, patients were monitored continuously with automatic noninvasive arterial blood pressure (NIABP), pulse oximetry (SpO2), ECG, capnometry-end-tidal $\mathrm{CO} 2$ (EtCO2), and peripheral temperature. Central venous pressure (CVP) in the right internal jugular vein was determined and controlled when necessary in accordance with indications (to guide the fluid therapy). After vascular assessment by a large bore 14-16 FG cannula in the back of the hand, premedication induction of anaesthesia and tracheal intubation with controlled mechanical ventilation with oxygen was provided. Normal saline at an average rate of $10-12 \mathrm{ml} / \mathrm{kg} / \mathrm{h}$ and more, as indicated by haemodynamics, was applied from the start of surgery until the renal vessels were unclamped. For protection of graft during vascular anastomosis, before unclamping, mild volume expansion with normal saline, $500 \mathrm{mg}$ solumedrol (methylpredno- solon), and 1-1.5 g/kg mannitol was applied. After completing vascular anastomosis, furosemide (up to 180-200 $\mathrm{mg}$ ) was injected in increments to enhance diuresis of the transplant. Packed red blood cells, plasma, and 5\% albumin were transfused to offset intraoperative bloodloss and to maintain a satisfactory level of hematocrite in the accordance with indications. Occasionally, a low-dose dopamine infusion $(2-4 \mu \mathrm{kg} / \mathrm{kg} / \mathrm{min})$ was used to increase blood pressure and improve perfusion of graft. Kidney turgidity was evaluated by the surgical team members for assessment of the hydration regimen.

Haemodynamic parameters were measured prior to premedication and induction of anaesthesia, immediately afterwards, and during anaesthesia up to end of surgery, with the special attention to the time of graft reperfusion. Cardiovascular instability was determined by measuring changes in excess of $20 \%$ of basal systolic blood pressure (SBP) after induction of anaesthesia and $<95 \mathrm{~mm} \mathrm{Hg}$ at the reperfusion time. The incidence in percentage $(\%)$ of severe hypertention and hypotension after induction of anaesthesia and just after reperfusion, as well as CVP at time of declamping was recorded. The total volume of fluids and restoration of transplant function (immediate, delayed and non-function) were controlled. All patients after completion of surgery were observed carefully for signs of residual myorelaxation, fluid overload and dehydratation. The hourly urine output was replaced with normal saline $1 \mathrm{~mL}$ for each $\mathrm{mL}$ of urine.

With the aim to investigate the relationship between the use of potentially nefrotoxic inhalation anaesthetic sevoflurane and recovery profiles of kidney function the incidence of immediate, delayed graft function as well non-function was analysed in 12 patients who developed arterial hypotension with SBP up to $95-85 \mathrm{~mm} \mathrm{Hg}$ at the time of reperfusion. These data were compared with the same parameters of the isoflurane group. Statistical analysis was performed with the Statistical Package for the Social Sciences (SPSS 14.0). Demographic and perioperative data were compared using the Student's $t$-test. A value of $P<0.05$ was taken as statistically significant.

\section{RESULTS}

Stage I. The retrospective study found that $40 \%$ of involved patients were anaemic with $\mathrm{Hb} 7 \%$ and $\mathrm{Ht} 20 \%$, with hypoproteinaemia. $80 \%$ of the recipients demonstrated initial severe arterial hypertension with SBP that varied from 170 to $230 \mathrm{~mm} \mathrm{Hg}(180 \pm 20 \mathrm{~mm} \mathrm{Hg})$ and diastolic blood pressure (DBP) greater than $110 \mathrm{~mm} \mathrm{Hg}(112 \pm 15 \mathrm{~mm} \mathrm{Hg})$. Study of erythrocyte morfology (by Dr.habil.biol. Velta Ose, Institute of Microbiology, personal communication) revealed dramatic changes of shape of erythrocytes that accompanied severe anaemia; many codocytes, stomatocytes, and echinocytes were detected and identified as the potential cause of blood reology disorders due to deformity and rigidity (Fig. 1). After induction of anaesthesia with barbiturates and neuroleptanalgesics, SBP decreased significantly in all hypertensive patients by $40 \pm 20 \%(P<0.05)$, compared with the 


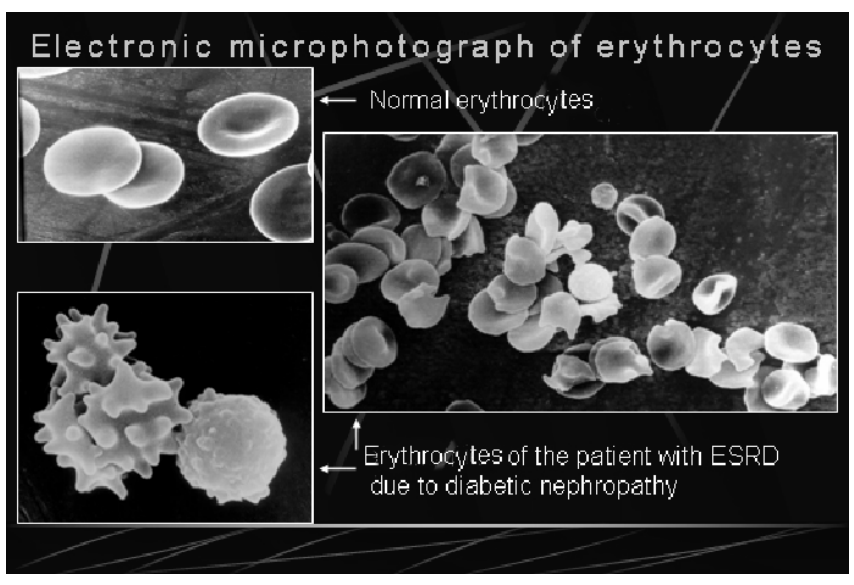

Fig. 1. Electronic microphotograph of erythrocytes of the patients with end-stage renal disease due to diabetic nephropathy in comparison with normal erythrocytes.

initial level. Immediately after tracheal intubation and during the early postintubation period, all hypertensive patients given nitrous oxide for maintenance of anaesthesia remained hypertensive during the operation and anaesthesia. However, careful administration of halothane seemed to be the most favourable method for controlling haemodynamic stability in hypertensive patients. We did not find any evidence that halothane deteriorated kidney function. The use of a combination of barbiturates with sodium oxybutyrate or sodium oxybutyrate alone for induction prevented significant hypotension in normotensive patients. The steroid anaesthetic viadril demonstrated a moderate hypotensive effect (15-17\% of patients) and was an appropriate agent for induction in hypertensive patient. Unfortunately, this drug caused irritation of venous walls and induced local trombophlebitis. Significant harmful effect of the used methods of anaesthesia on haemodynamic at time of graft reperfusion moment was not shown. The main perioperative complications during this stage of anaesthesia system development was haemodynamic instability, which occurred in $60 \%$ of cases. Apnea due to central depression and peripheral neuromuscular blockade with prolonged artificial ventilation for 2-6 hrs after the end of surgery was detected in $1.8 \%$ of patients. Two patients died due to underlying comorbid conditions, including hyperhydration and oedema pulmonum.

In conclusion: in this stage the same anaesthetics and analgesics were used for renal transplantation in Latvia as were used worldwide. It was possible to carry out anaesthesia during renal transplantation using the combination of non-inhalation and inhalation anaesthetics, the selection of which was dependent on the excretory function of kidneys of recipients and also haemodynamic data. However, there was no optimal method of anaesthesia. The main problem was inability to use a safe muscle relaxant not requiring renal function for its elimination. Unfortunately, use of succinylholine was limited due to its known hyperkalemic effect and potential cardiac arrest.

Stage II. The demographic characteristics of the recipients and their corresponding donors as well as donor organ cold ischemia and duration of surgery did not differ significantly between the two groups of this study stage. Patients of both groups had similar haemodynamics. Arterial hypertension was detected in both groups. In $75 \%$ of cases SBP exceeded $170 \mathrm{~mm} \mathrm{Hg}$ and was on average $180 \pm 15 \%$, DBP $-95 \pm 10$ $\mathrm{mm} \mathrm{Hg}$. In 61 patients with severe arterial hypertension (41.03\%), myocardial hypoxia was detected on ECG. Premedication with the sedative drug midasolam (in average $2,5 \mathrm{mg})$ and strong opioid fentanyl $(0.15-0.2 \mathrm{mg})$, and careful use of a sleeping dose of propofol by titration method (120-200 mg) provided uncomplicated induction in anaesthesia and endotracheal intubation in all patients. Midasolam-propofol induction resulted in decrease of SBP by $18 \pm$ $5 \%$, compared with the initial level. In TIVA group by careful titrating of propofol infusion it was possible to stabilise and regulate arterial pressure at the necessary level (12-16\% under initial) throughout, and to increase the level during graft reperfusion. We did not observe substantial haemodynamic changes during anaesthesia, nor after kidney reperfusion. Adequate anaesthesia was obtained by an intraoperative dose of $450 \pm 100 \mathrm{mg}$ propofol, $0.5-0.7 \mathrm{mg}$ fentanyl, and $110 \pm 20 \mathrm{mg}$ atracurium. Recovery was rapid and occured $11 \pm 4 \mathrm{~min}$ after end of infusion. None of the patients experienced nausea and vomiting. The patients achieved and maintained high recovery scores. A high proportion of immediate graft function was achieved. In conclusion: propofol has been successfully used for total intravenous anaesthesia for kidney transplant surgery, and was associated with a reduction in postoperative nausea and vomiting.

Isoflurane in concentration $0.8-1 \mathrm{MAK}$ for maintenance of anaesthesia induced moderate vasoplegic and hypotensive effect. SBP was stabilised at a $17 \pm 5 \%$ level and DBP at a $10 \pm 6 \%$ level under initial. The study found no significant difference in haemodynamic changes between TIVA and isoflurane groups during renal transplantation $(P>0.05)$. However, isoflurane improved peripheral circulation more than propofol. Peripheral temperature was $0.8-1{ }^{\circ} \mathrm{C}$ higher in the isoflurane group in comparison with the propofol group.

In conclusion: combined general anaesthesia with isoflurane produced excellent conditions for the operation with rather prompt recovery after $16 \pm 5 \mathrm{~min}$. The recovery period was slightly longer than in the propofol group, which may be explained by intensification of muscle relaxant effect. In these two groups sufficient renal blood perfusion in the graft was achieved. However, the main postoperative problem in the isoflurane group was shivering as a consequence of vasodilatation. Results of the study shown that isoflurane-like propofol may be an agent of choice for renal transplantation.

Stage III. The demographic and clinical characteristics of the patients involved in the study are given in Table 4.

There were no significant differences between groups with respect to demographic characteristics of the recipients and incidence of severe and moderate hypertension before sur- 
THE DEMOGRAPHIC AND CLINICAL CHARACTERISTIC OF THE PATIENTS INVOLVED IN THE STAGE III (2008-2011)

\begin{tabular}{l|c|c}
\hline \multirow{2}{*}{ Test } & \multicolumn{2}{|c}{ Patient groups } \\
\cline { 2 - 3 } & $\begin{array}{c}\text { sevoflurane group } \\
(\mathrm{n}=90)\end{array}$ & $\begin{array}{c}\text { isoflurane ,b” group } \\
(\mathrm{n}=90)\end{array}$ \\
\hline Age, yrs & & 27 \\
$<40$ & 21 & 36 \\
$41-50$ & 43 & 21 \\
$51-60$ & 18 & 6 \\
$>60$ & 8 & $52(57.8 \%)$ \\
Sex & & $38(42.2 \%)$ \\
$\quad$ Male & $54(60 \%)$ & $44(48.9 \%)$ \\
$\quad$ Female & $36(40 \%)$ & $35(38.9 \%)$ \\
With & & $11(12.2 \%)$ \\
$\quad$ severe hypertension & $50(55.6 \%)$ & \\
moderate hypertension & $36(40 \%)$ & \\
normotensive & $4(4.4 \%)$ & \\
& &
\end{tabular}

gery and anaesthesia. The proportion of normotensive patients was lower in the sevoflurane group. Data on the haemodynamic reaction to combined general anaesthesia with propofol -isoflurane and propofol-sevoflurane are given in Table 5.

Arterial blood pressure decreased significantly (in excess of $20 \%$ of basal systolic blood pressure, $P<0.05$ ) after induction with propofol-midasolam-fentanyl in both groups of patients, but no patients developed severe arterial hypotension due to arterial hypertension before surgery. A significant difference between groups was not detected in hypotensive reaction to induction of anaesthesia and immediately afterwards. At the time of graft reperfusion the incidence of hypotension was slightly higher in patients anaesthetised with isoflurane than in those who received sevoflurane, but this difference was not significant $(P>0.05)$. CVP data showed that both patient groups were euvolaemic at the time of reperfusion of transplant. Analysis of graft function after short hypotention at reperfusion indicated that kidney functioned immediately in $75 \%$ of cases, but delayed function was seen in $25 \%$. There were no differences between groups.

\section{DISCUSSION}

Successful treatment of patients with ESRD by kidney transplantation cannot be carried out without taking into consideration the perioperative anaesthetic management and strategies. The effect of drugs on recipient, the effect of drugs on the function of the transplanted kidney and the effect of drugs that depend on the transplanted kidney for their elimination should be taken into account (Sondore et al., 1994). Patients with ESRD present many problems to the anaesthesiologists. The majority of patients suffer from some degree of hypertension and may be on antihypertensive drug therapy. Hypotension may occur during anaes-
THE INCIDENCE OF HYPOTENSIVE REACTION AFTER INDUCTION OF ANAESTHESIA WITH PROPOFOL AND AT THE TIME OF GRAFT REPERFUSION DURING ANAESTHESIA WITH SEVOFLURANE AND ISOFLURANE (2008-2011)

\begin{tabular}{l|c|c}
\hline \multirow{2}{*}{ Test } & \multicolumn{2}{c}{ Patient groups } \\
\cline { 2 - 3 } & $\begin{array}{c}\text { Sevoflurane } \\
\text { group }\end{array}$ & $\begin{array}{c}\text { Isoflurane } \\
\text { group }\end{array}$ \\
\hline $\begin{array}{l}\text { Incidence of hypotension, \% (SAB than } \\
\text { 20\% from initial level after induction of } \\
\text { anaesthesia) }\end{array}$ & $30.6 \pm 9.2$ & $31.33 \pm 4.6$ \\
$\begin{array}{l}\text { Incidence of hypotension, \% (SAB 95 mm } \\
\mathrm{Hg} \text { at the moment of graft reperfusion }\end{array}$ & $16.37 \pm 4.8$ & $18.64 \pm 5.2$ \\
CVP at time of declamping, mmHg & $13.4 \pm 3.4$ & $12.5 \pm 3.2$
\end{tabular}

thesia due to interaction of antihypertensive drugs and due to haemodynamical effects of anaesthetics. Hypovolaemia must be avoided, as hypotension increases the possibility of acute tubular necrosis in the transplant (Carlier et al.,1982; O'Malley et al., 2002; Hadimioglu et al., 2008; Othman et al., 2010). In stage I of the kidney transplant development in the period 1973 to 1990 , viadril, barbiturates, sodium oxybutyrate, and neuroleptanalgesia were used for induction of anaesthesia, while for maintenance the volatile anaesthetics nitrous oxide and halothane with opioid fentanyl and different available muscle relaxants, including long-acting, were used. Nitrous oxide has not been shown to have any effects on the kidney function, but in anaemic patients with ESRD it may seriously impair the oxygen-carrying capacity (Mazze et al., 1974). Therefore, use of nitrous oxide for anaesthesia in transplants was later avoided and in some cases contrindicated. Halothane in stage I of clinical experience was probably the most widely used volatile anaesthetic. Unfortunately, halothane was not an ideal anaesthetic also due to potential hepatotoxic effect and high metabolic rate. The main perioperative complications of that period were haemodynamic instability during anaesthesia (in $60 \%$ of cases) and apnea due to central depression and peripheral neuromuscular blockade with need for prolonged postoperative artificial ventilation. Two patients died due to underlying comorbid conditions, including hyperhydration and $o e$ dema pulmonum.

In stage II, propofol was successfully implemented for total intravenous anaesthesia for kidney transplantation. Smooth, rapid induction and rapid clear headed recovery should be mentioned among the advantages of propofol. However, it may decrease arterial pressure, cardiac output and systemic vascular resistance. No patients in the TIVA group developed severe arterial hypotension. By careful titrating of propofol infusion arterial pressure was stabilised on the necessary level. Substantial haemodynamic changes at the time of graft reperfusion were not seen.

As most of the recipients were hypertensive, intravenous opioids such as fentanyl, were usually used not only for analgesia, but also with the aim to blunt the stress response to laryngoscopy and tracheal intubation. Its excretion is 
mainly by hepatic metabolism. In our study fentanyl was successfully used in normal doses (Koehntop and Rodman, 1997). The non-depolarising relaxant atracurium has advantages, as it is broken down by Hofmann degradation. It was the main drug of choice for muscle relaxation in our study.

Haemodynamic changes that accompany TIVA were observed in the isoflurane group ,a”. Minimal metabolism $(0.2 \%)$, lack of toxicity, improvement of coronary and peripheral circulation, and decreased requirement for muscle relaxants make isoflurane a suitable drug for anaesthesia in patients with ESRD. In accordance with published data, it has less effect on cardiac output and renal blood flow than another anaesthetics. However, hypotension that may develop during isoflurane anaesthesia should be taken into account.

During stage III of clinical renal transplantation, the volatile agent sevoflurane has been used in patients undergoing renal transplantation. Some authorities do not recommend sevoflurane for anaesthesia during renal transplantation. It has been considered undesirable due to potential toxic fluoride accumulation after $2-4 \mathrm{~h}$ of anaesthesia. However, most studies have not found any detectable postoperative impairement of renal function using this drug (Kharasch et al., 1997). We did not observe any harmful effect of sevoflurane on kidney transplantation outcome. Comparative evaluation of kidney function in the sevoflurane and isoflurane groups showed no differences in immediate or delayed function. The immediate start of diuresis was found in $75 \%$, delayed in $25 \%$, and non-function was not seen in both groups.

The conclusion is that adequate renal blood flow is essential for good donor kidney function. Good perfusion of the new kidney is dependent on adequate intravascular volume and the avoidance of hypotension. Controversy exists regarding the optimal anaesthesia method for renal transplantation. Optimisation of the anaesthesia method in Latvian Centre of Renal Transplantation has been ongoing along with the development of pharmacology for anaesthesiology. Our clinical experience demonstrated that general anaesthesia can be safely provided by carefully induced intravenous induction agents, preferably propofol, given slowly after premedication with benzodiazepine midasolam and opioid fentanyl. Maintenance of general anaesthesia can be satisfactorily achieved by total intravenous anaesthesia using propofol as the main anaesthetic, as well as with inhalational anaesthetics isoflurane and sevoflurane. During renal transplantation, anaesthesiologists must optimise volume status, perfusion pressure and promote survival of the renal graft.

\section{REFERENCES}

Akpek, E. A., Kayhan, Z., Donmez, A., Morey, G., Arslan, G. (2002). Early postoperative renal function following renal transplantation surgery. Effect of anesthetic technique. J. Anesth., 16, 114.

Carlier, M., Souifflet, J. P., Pirson, Y. (1982). Maximal hydration during anesthesia increases pulmonary arterial pressures and improves early function of human transplants. Transplantation, 34, 201-204.
Davie, I. T. (1979). Anesthesia in renal transplantation. In: Chatterjee, S. N. Manual of Renal Transplantation (pp. 87-100). New York, Heidelberg, Berlin: Springer-Verlag.

de Gasperi, A., Mazza, E., Noe, L., Corti, A., Cristalli, A., Prosperi, M., Sabbadini, D., Savi, M. C., Vai, S. (1996). Pharmacokinetic profile of the induction dose of propofol in chronic renal failure patients undergoig renal transplantation. Minerva Anaesthesiol., 62, 25-31.

Eger, E., 2nd, Koblin, D. D., Bowland, T., Ionescu, P., Laster, M.J., Fang, Z., Gong, D., Sonner, J., Weiskopf, R. B. (1977). Nephrotoxicity of sevoflurane versus desflurane anesthesia in volunteers. Anesth. Analg., 84, $160-168$.

Fahey, M., Rupp, S. M., Fisher, D. M., Miller, R. D., Sharma, M., Canfell, C., Castagnoli, K., Hennis, P. J. (1984). The pharmacokinetics and pharmacodynamics of atracurium in patients with and without renal failure. Anaesthesiology, 61, 699-702

Hadimioglu, N., Saadawy, I., Saglam, T., Ertug, Z., Dinckan, A. (2008). The effect of different crystalloid solutions on acid-base balance and early kidney function after kidney transplantation. Anesth. Analg., 7 (1), 264-269.

Kharasch, E. S., Frink, E. J., Zager, R. Bowdle, T. A., Artru, A., Nogami, W. M. (1997). Assessment of low-flow sevoflurane and isoflurane effects on renal function using sensitive markers of tubular toxicity. Anesthesiology, 86, 1238-1254.

Kirvela, M., Olkkola, K. T., Rosenberg, P. H., Yli-Hankala, A., Salmela, K., Lindgren, L. (1992). Pharmacokinetics of propofol and haemodynamic changes during induction of anaesthesia in uraemic patients. Brit. J. Anaesth., 68, 178-182.

Koehntop, D. E., Rodman, J. H. (1997). Fentanyl pharmakokinetics in patients undergoing renal transplantation. Pharmacotherapy, 17 (4), 746-752.

Mazze, R., Cousins, M. J., Barr, G. A. (1974). Renal effects and metabolism of isoflurane in man. Anaesthesiology, 40, 536-542.

Mitre, L., Sondore, A., Matulēna, I., Rozīte, V. (1994). Propofola izvēle ievadanestēzijā un anestēzijas saglabāšanā nieru transplantācijas operācijās. I Latvijas anestezioloǵijas, reanimatoloǵijas, intensīvās terapijas, neatliekamās un katastrofu medicīnas kongresa materiāli. Rīga, 75. lpp.

O’Malley, C. M. N., Frumento, R. J., Bennet-Cuerrero, E. (2002). Intravenous fluid therapy in renal transplant recipirents: Results of US survey. Transplant Proc., 34, 3142-3145.

Othman, M. M., Ismael, A. Z., Hammouda, G. E. (2010). The impact of timing of maximal crystalloid hydration on early graft function during kidney transplantation. Anesth. Analg., 110 (5), 1440-1445.

Perico, N., Cattaneo, D. Sayegh MH, Remuzzi G. (2004). Delayed graft function in kidney transplantation. Lancet, 364, 1814.

Sondore, A., Mitre, L., Rozīte, V., Matulēna I. (1994). Atrakūrija neiromuskulārie efekti slimniekiem ar terminālo nieru mazspēju operācijas nieru transplantācijas laikā. I Latvijas anestezioloǵijas, reanimatoloğijas, intensīvās terapijas, neatliekamās un katastrofu medicīnas kongresa materiāli. Rīga, 78. lpp.

Sondore, A., Rozìte, V. (1990). Anesteziolog̣ijas problēmas nieru transplantācijā. Latvijas Ārsts, Nr. 6, 26-30.

Sondore, A., Rozīte, V., Mitre, L., Matulēna, I. (1994). Izoflurāna drošība augsta kirurğiska riska pacientiem. I Latvijas anestezioloǵijas, reanimatologijas, intensīvās terapijas, neatliekamās un katastrofu medicīnas kongresa materiāli. Rīga, 77. lpp.

Sondore, A., Vanags, I., Kokars, I. (1998). Izoflurāna klīniskā farmakolog̣ija un tā lietošanas pirmā pieredze Latvijā. Latvijas Ārsts, Nr. 5, 33-36.

Sondore, A., Vanags, I., Kokars, I. (2000). Jaunākā inhalējamā narkotiskā viela sevoflurāns anestezioloǵijā. Latvijas Ārstu Žurnāls, Nr. 2, 13-17.

Thomas, M. C., Mathew, T. H., Russ, G. R. Rao, M. M., Moran, J. (2003). Periopertative blood pressure control, delayed graft function and acute rejection after renal transplantation. Transplantation, 75, 1989-1995. 


\section{VISPĀRĒJA ANESTĒZIJA NIERES TRANSPLANTĀCIJĀ LATVIJĀ: KRITISKA ANALĪZE, BALSTĪTA UZ KLĪNISKO PIEREDZI}

Pēdējos 40 gados ķirurǵisko operāciju anestezioloǵiskajā nodrošinājumā notikušas būtiskas pārmaiņas, kuras skārušas arī transplantoloǵijas nozari. Viens no svarīgajiem nieru transplantāta funkcijas atjaunošanas un akūtas tubulārās nekrozes novēršanas noteikumiem ir hemodinamiskā stabilitāte, īpaši asinsrites atjaunošanas brīdī. Pētījuma mērḳis bija dažādo kopš 1973. gada lietoto anestēzijas metožu drošības un efektivitātes vērtējums, pievēršot īpašu uzmanību to izraisītām hemodinamiskām reakcijām. Tika veikta anestēzijas protokolu retrospektīvā analīze, kas skāra 607 pacientus ar hronisku nieru mazspēju terminālā fāzē, vecumā no 17 līdz 75 gadiem, riska grupās ASA III/IV, operētiem vispārējā anestēzijā šādos periodos: 1973-1990 (I etaps, 282 pacienti); 1991-2000 (II etaps,145 pacienti); $2001-2011$ (III etaps, 180 pacienti). Hemodinamikas rādìtāji (sistoliskais, diastoliskais, vidējais arteriālais spiediens un centrālais venozais spiediens tika reǵistrēti pirms premedikācijas un ievadnarkozes, pēc ievadnarkozes un tūdal pēc intubācijas, kā arī operācijas laikā, īpaši pievēršot tiem uzmanību transplantāta reperfūzijas brīdī. Viena no svarīgākām I etapa perioperatīvām problēmām bija hemodinamiskā nestabilitāte viadrīla, barbiturātu, neiroleptanalgētiku, halotāna un slāpekḷa oksidūla ietekmē, kas skāra $60 \%$ pacientu, kā arī ilgstoša apnoja respiratorās depresijas un antidepolarizējošo relaksantu darbības dēḷ. Šajā etapā nomira divi pacienti ar izteiktiem vitālo funkciju traucējumiem, hiperhidratāciju un plaušu tūsku. Vispārējā intravenozā anestēzija ar propofola infūziju un vispārēja anestēzija ar propofolu-izoflurānu (II etaps) ievērojumus hemodinamikas traucējumus neizraisīja. III etapā gūtā pieredze apliecināja, ka transplantāta reperfūzijas laikā izoflurāna anestēzijai piemīt lielāks hipotensīvais efekts salīdzinot ar sevoflurānu, bet šī starpība nebija statistiski ticama $(P<0.05)$. Abās pacientu grupās transplantāta primārā funkcija tika reǵistrēta $75 \%$, bet atliktā $-25 \%$ gadījumu. Vispārēja anestēzija ar moderniem anestēzijas līdzekḷiem un metodēm, lietojot propofola infūziju kombinācijā ar benzodiazepīnu midazolāmu un opioīdu fentanīlu, kā arī vispārējā kombinētā anestēzija ar propofolu-izoflurānu, propofolu-sevoflurānu, benzodiazepīnu midazolāmu un opiōidu fentanīlu var nodrošināt efektīvu perioperatīvo aprūpi nieru transplantācijas laikā. Īpaša uzmanība jāpievērš svarīgajiem pārstādītas nieres funkcijas garantiem — pacienta volēmijas stāvoklim un transplantāta perfūzijas spiedienam asinsrites atjaunošanas momentā. 